\title{
Seven Steps Around the Fire: A World of Illusion
}

\author{
Zeba Mehdi, Shravan Kumar
}

\begin{abstract}
The paper aims at discussing the prevailing hollowness in the lives of the characters. The ray of hope gets broken by the brutal realities of the society. The characters of the play do not realise that the world has never changed; it's the same one that believes in curbing the high flights of the people. The truth, hope, and loyalty fall flat before the treacherous society. The present paper intends to highlight human psyche that is the result of every kind of insanity. The paper also focuses on the futility of various developments that have not brought about any change in the lives of the neglected people. The present paper is an effort to delineate the prevailing illusionary society. The paper deals with the fact that being happy and contented becomes an illusion for the marginalized sections of the society and the foundation of inequality lies deep in the hearts of people, that seem rather impossible to tackle with.
\end{abstract}

Key words: Marginalised; Transgender; Submission; Brutality; Social Ills.

\section{INTRODUCTION} highlight the tabooed subjects. His plays have been categorized as the problem plays. The problems are related to the society and its functions that sometimes clash with the individual and create havoc in the lives of the concerned person. His plays basically focus on the plight of the marginalised class of the society. He follows the path of Ibsen and Shaw. Their writings inspired him a lot and he started writing for the masses. Beena Agarwal comments:

He prepared the stage for a specific realism on the lines of Ibsen and Shaw.

For him, man is an integral part of society and consciously or unconsciously

the creeping influences of societal set up, determine the fabric of relationship

around him. (Agarwal, 25)

Dattani's plays are an eye opener for the modernists who claim to have a developed society, whereas the weaker section still lies beneath. The term 'modern' is superficial in nature and does not bring equality to the people impartially. The playwright leaves no stone unturned in changing the society as a whole. He tries to focus on the plight of the marginalized class in such a way so as to move the powerful to introduce favourable changes in the society. His choice of characters determines the success of the play. The overall picture of the society is demonstrated by the spoken words of the characters. The characters project the realistic picture of

Revised Manuscript Received on November 11, 2019.

Zeba Mehdi, Research Scholar, AIESR, Amity University, Noida,Uttar Pradesh.

Dr Shravan Kumar, Assistant Professor, AIESR, Amity University, Noida,Uttar Pradesh.
Mahesh Dattani, a writer of fine intellect, does not hesitate to

* Correspondence Author

the world properly. He himself praises his characters and comments:

"I also know that I have lot to say and am probably not saying it well enough.

But my characters have a lot to say too, and they seem to be doing rather well

at having their say. Every time a critic says something awful about my writing,

I realise that they are pointing out something that I have wanted to say and have,

as usual, been hopeless and unconvincing. Every time audiences have applauded,

laughed, cried or simply offered their silence in response to some moment in the play,

I am completely aware that it is my character that has done the work for me".

(Dattani, Preface)

Dattani is concerned about the neglected sections of the society for which he deals with a number of subjects focusing on the deteriorating condition of the society. The society shows as if they are treated equally but it's only on paper. Its weaker section still cries for some relief. Dattani, being a problem playwright, does his job effectively. All of his plays target the problematic area and depict the blatant lie of development. Chaudhuri praises Dattani's art and says:

"Dattani obviously seems to have a point to make to his audience.

But rather than directly preach, the playwright dramatizes the People's performance on the stage with characters one begins to identify with, facing genuine, real life problems. The play, then, in a sense, is a plea for empathy and sensitivity to India's queer culture (51)

Seven steps around the fire is a wonderful play by Dattani that deals with the two worlds. Both the worlds live in a kind of illusion, one for its superiority and the other for its betterment. Their things fall apart when they collide with each other, devastating the latter one with a slight sense on the part of the first one even that does not make any difference and the things go smoothly for them. Dattani prefers theatre more than any other genre of literature. He believes in theatre and says:

"Audience need to make the effort. Unlike TV or cinema where the viewer doesn't have to contribute, theatre is a collective experience. In fact, at a moment of truth, you will find how people who don't know each other join in from all corners of the darkened hall to applaud and declare their appreciation of that important moment. And that's when you know a play works". (Nair)

Oscar Wilde strongly feels the same. He says:

"I regard the theatre as the greatest of all art forms, the most immediate way in which a human being can share with another the sense of what it is to be a human being". (Online) 
Seven Steps Around the Fire was first broadcasted as Seven Circles Around the Fire by BBC Radio on 9th January 1999. The play's first performance has been on 6th August 1999 on stage at the Museum Theatre by MTC Production \& The Madras Theatre, Chennai with Anuradha Ananth, Victor Paulraj, Kartik Iyer, Sourabh Ahuja, Sudhir Ahuja, P.C. Ramakrishna and Asim Sharma, directed by Mithran Devanesen. Later, it was named as 'Seven Steps Around the Fire'.

Dattani's selected play acts as an eye opener for the modern generations to be sane human beings rather than insane. The society as a whole should be impartial even for its weakest section, only then it can be a worth living society. The modern world does not belong to any one section of society but it is all together for the whole world including the weakest and disabled sections as well. But these days the power has taken over all the fields of society be it social, political, or personal, the capricious reign rules.

Seven Steps Around the Fire deals with the inbuilt illusion of the characters who want to get positive response of every action of theirs. Dattani has used about ten characters in the play for the first time; he generally has 6-7 characters in his plays. All the characters contribute to the development of the play. Almost all the characters in the play are decisive in nature; they plan things on their own without having any prediction about the result of their actions. The optimism in the play faces a big fall due to the prevailing haphazard system in the society. Dattani in Preface expresses the need of being a voice to the unvoiced. He feels that time needs someone to vocalize the voiceless sections of the society. He is quite confident that he is able to do the task. He states:

"I am certain that my plays are a true reflection of my time, place and socio-economic background. I am hugely excited and curious to know what the future holds for me and my art in the new millennium in a country that has a myriad challenges to face politically, socially, artistically and culturally. Where does one begin? By ending this preface and carrying on with the business of holding a mirror up to society". (Dattani, xv)

The central character of the play, Uma introduces the other characters through her interactions. Uma, who is the wife of Suresh, a superintendent of police, is working on her thesis for which she takes up Kamala's case as a study for research. She faces numerous problems while doing so as Kamala is a transgender who gets killed in mysterious circumstances. Even a constable does not understand the need of selecting Kamla's case. He says:

MUNSWAMY. Madam, if you don't mind me saying, why is a lady from a respectable family like yourself. . .?

There are so many other cases. All murder cases. Man killing wife, wife killing man's lover, brother killing brother. And that shelf is full of dowry cases. Shall I ask the peon to dust all those files?

UMA. No. maybe some other time. I think this particular one is of interest to me at this time. (Dattani, 7)

The play begins in a dramatic way, and confuses the audience. The marriage mantras and terrible cries all together create a tense environment. The beginning results in more curiosity about the development and concluding scenes. The beginning of the play confirms about the upcoming dangerous events.

"Sanskrit mantras fade in, the Ines chanted during a Hindu wedding. Fire.
The sound of the fire grows louder, drowning the mantras. A scream. The flames engulf the scream". (Dattani, 7)

Uma's selfless efforts to find out the real culprit end in revealing the naked reality of the society. The whole play is a kind of a surprise for the readers as the concluding scene is a blow on the modern face of the society.

When police has got a pressure from upwards to solve the murder mystery of Kamala, it takes Anarkali in to custody and closes the file. She is brutally treated by the male prisoners. When Uma raises her voice against this, her husband asks her to stay away from legal matters.

Uma investigates from Anarkali and Hijra boss about the background of Kamala, and supposed to be the responsible incidents for her murder. But she feels that reality is being hidden. She does not lose hope and tries to get to the main culprit.

Munnaswamy, a constable helps Uma in her efforts to bring out the truth of Kamala's murder but he always asks her to stay away from transgender. Uma's husband Suresh does not like her too much involvement in Kamala's case. He asks her to take some other topic for her research but she disagrees to it. Uma's various visits to the police station and her conversation depicts the fact that the society hates the transgender to the height of animosity and even its vice-versa. The society norms have parted the ways of two people. The straight consider them to be on the right path, the transgender fumes at it. The humiliation that they feel at the hands of society makes them stricter towards the straights.

Uma. I would like to meet Anarkali. Where is she?

Munswamy. Anarkali, come here.

Anarkali. No! I don't want to meet any journalist.

Munswamy. I will come inside and beat you up, you worthless pig!

Anarkali. I am not in a mood.

Uma. I am not a journalist.

Anarkali. I don't care if you are the mother of all whores in Bangalore. I said

I am not in the mood! (Dattani, 8)

Munnaswamy has been taken from a real-life character. Generally, all people try to avoid transgender and police is to deal with them, they forget any ethics and misbehave like hell. His character throes light on the fact that the society still bows down before the powerful.

Munnaswami: She! Of course, it will talk to you. We will beat it up if it does not.

(Dattani,7)

Suresh, a well-placed police officer, is a no exception in the case of the marginalized. When Uma interacts with him and discusses about transgender before him, he remarks filthy and tries to deviates from the path.

Uma. Why do they put her in a male prison?

Suresh. They are as strong as horses. Wear the purple one.

Uma. I wore that last night.

Suresh. Again. (Dattani, 9)

He further says:

Suresh. Good. Don't believe a word of anything it says. They are all liars. (Dattani, 9)

The play's tone is real and rough. It is Dattani's quality to describe the real in reel so artistically. The prolonged conversations between Uma and Anarkali and Munnaswamy reveal that no part of society easily accepts the other and this

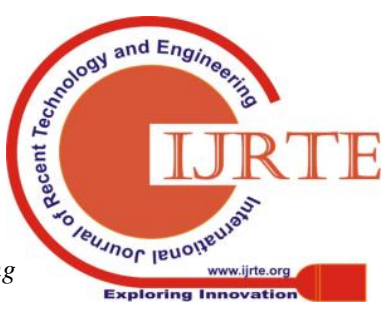


remains the unchallenged fact. It really poses difficulties for those who aim at doing something unconventional. Indian society has always been so closed and conservative; it's not an easy task to introduce changes in it. The very step towards the change generates criticism that even can be risky for one's life as well.

Dattani's plays project the unconditional love for traditions and hatred for the transgender. The society has itself made some legal and illegal notions and is mandatory for the young generation to follow them. The present play faces the same challenges and the targeted people meet with a terrible end only because the societal rites have not been followed. In fact, the rules and regulations are meant for the suppressed class, the privileged section of the society enjoys full freedom.

Uma is projected as the sensitive social realistic class of the society who decides to unveil the truth behind Kamala's murder. She talks to Champa and plans for Anarkali's bail. Champa proves the innocence of Anarkali before Uma and clarifies that she can never even think of killing Kamala who she has always considered as her sister. Uma is not satisfied at the arrest of Anarkali for killing Kamala. She wants to find out the things on her own. She plans to visit the place where all transgenders reside. She reaches and tries to take out the reality out of Champa's mouth, but finds the innocence of Anarkali. After talking to Champa, she feels relieved as she understands the whole situation and decides to meet $\mathrm{Mr}$. Sharma in this regard. The conversation below throws light on the helplessness of Champa along with her rude behaviour. She does not accept help at once but goes for cross questioning. The conversation shows a line of segregation between the two worlds.

Champa. What a question to ask!

Uma. She-she did not kill Kamla, did she?

Champa. Yes, yes. That won't suit you. No. she did not kill Kamla.

They were sisters.

UMA. If I gave you money, will you go to the court and get her release orders?

CHAMPA. Did I come begging you-please give me money to save my daughter? Huh?

UMA. (opens her bag). Here.

CHAMPA. Aah, these old bones! How much is it?

UMA. Enough for the bail amount and some more for your trouble.

(Dattani, 24-25)

Dattani maintains coherence in his plays to present the social ills and its aftermaths. When something wrong has taken place, how the other connected things be normalized. He divides the society into parts, one is with the wrong and the other is against the ill, but being a realistic play, the wrong wins in the end and proves the importance of power over moral in modern world. The realism is all about the projection of incidents as such. Realism deals with realistic depiction

"Realism, in literature, is a manner and method of picturing life as it really is, untouched by idealism or romanticism. As a manner of writing, realism relies on the use of specific details to interpret life faithfully and objectively. In contrast to romance, this is concerned with the bizarre and psychological in its approach to character, presenting the individual rather than the type. Often, fate plays a major role in the action. Realism became prominent in the English novel with such writers as Daniel Defoe, Samuel Richardson, Henry Fielding,
Tobias Smollett, Lawrence Sterne, Jane Austen, Charlotte Bronte, Anthony Trollope and William Makepeace Thackeray."(Coles dictionary, 163)

Uma's efforts of bringing out the reason and person behind the murder of Kamala get fulfilled and the truth comes out with a shriek.

Uma. The photograph was what Mr. Sharma was after. A Polaroid picture that Subbu

and Kamla had taken soon after their private wedding in some remote temple. . . A picture of Kamla as a beautiful bride smiling at Subbu with the wedding garland around him. The probably did not know that Kamla was not a woman. Of course Mr. Sharma couldn't have it--totally unacceptable. So he arranged to have Kamla burned to death. (Dattani, 41) Seven Steps Around the Fire, being a problem play, deals with the problem of illusion. The characters live in their own world of illusion where they feel everything will be in their control. Uma feels that her interrogation like a police man will benefit someone legally but it's a sheer dream. Kamala and Anarkali are friends and their compatibility makes them famous. Kamala is a pretty young transgender, who is liked by all. Even she is nominated to be the head of Hijras. There are many who hate her but her behaviour wins their hearts. Subbu, the only son of Mr. Sharma who is a minister, comes across Kamala and starts loving her from the core of his heart. He plans to marry her, but all hell breaks loose when his father comes to know about his decision of marrying a transgender. On the very day of their marriage, he burns Kamala alive, leaving Subbu insane. The very sight and cries of dying Kamala has ruined the life of Subbu. Everything gets devastated by Mr. Sharma's barbaric act, but a photograph of Subbu and Kamal in garland is with Champa. Mr. Sharma often sends Salim, a rouge to collect the photo but in vain.

Salim storms in, sending the bells tinkling wildly

Champa. I told you not to show your face here!

Salim. Shut up, you old bag! I told you to send me her things. Where is her trunk? Champa. Quiet, you fool! I have a guest here. A Memsaab. Madam, this is Salim. Do salaam to madam.

Salim. Salaam.

Champa. Now go away.

Salim. First give me her trunk. (Dattani, 26)

Dattani's presentation of the facts remains remarkable till the end of the play. He depicts the sequential vents though follow flashback technique. The reading of the story does help in visualizing the scenes. Beena Agarwal believes that:

His use of stage craft is extremely intricate and it makes the text echoing

multiple connotations. For dramatic representation is neither a matter of the

description nor of presentation but it is a matter of evocation. It is only with appropriate performance that the experience becomes vital. (30)

She further says:

Dattani's dramatic art is inspired by the mission to communicate profound meaning through his plays and, therefore, he exhibits keen awareness for the direction and stage performance of his own plays. His sensitive dramatic self is a fine synthesis of a dancer, director, actor, 
playwright, audience and commentator moving collectively towards a single direction. (Agarwal, 24)

Dattani webs a story in such a way so as to project the reality of the whole society. The main character and sensitive citizen of the country tries to punish the main culprit but forgets that money can buy everything. Uma's illusionary world does not make her think of the fact that the truth was known to all except her. She innocently reveals about Kamala's murder before her husband. She says:

Uma. Of course Mr. Sharma could not have it-totally unacceptable.

So he arranged to have Kamla burned to death. But Salim had to tell him about the picture. Mr. Sharma simply had to have that picture. He sent Salim to threaten Anarkali and Champa. . . He did get the picture eventually. . . after losing his son. What a price to pay!

And now he will be arrested and tried for murder.

Suresh. I don't know. . how do you know all this?

Uma. I have my resources. (Dattani, 41)

Even after knowing a different story from Uma, Suresh does not change his attitude towards Mr. Sharma. He even does not suspect him of being the culprit, he rather respects him more. The modern society trusts the powerful ones rather than the common men.

Suresh. Sir that is the truth. I have my resources to verify all this. Of course, they are all sworn to secrecy so. . . And Mr. Sharma's gratitude will be expressed in ways that will be, I am sure, more than adequate. . (Dattani, 41-42)

Dattani's play reveals societal injustice done to the weaker section of the society. A certain ideology encourages such kind of narrow thoughts. The society as a whole plays its game and imposes unnecessary restrictions in the lives of people. A. Nicoll states that:

"Many modern tragedies depend not on certain personalities presented

in isolated surroundings, but on individuals placed in the midst of social powers

from which they derive their joys and sorrows". (Nicoll, 97)

The play is, no doubt, a world of illusion where all the characters believe in their own imaginary world. Subbu and Kamala thought that their marriage would bless them and the things would be accepted later but nothing like that happened and Kamala had to bear the pain of terrible death. Subbu also suffered due to his illusionary world. Mr. Sharma, after killing Kamala, hoped to marry his son to a girl of his choice, the planning failed and his son dies the same day of his marriage. Uma has her own vision. She believes that she is going to help the police by catching Kamala's killer, she does not realize the fact the truth was in veil, it came as a surprise for her only. Jeremy Mortimer states:

"But it's Uma, a post-graduate student of sociology, who is the sleuth in this relationship, and using rather unconventional means, she uncovers the truth behind a murder in the city's hijra community". (Preface)

The play ends on a very concerning note. Uma gets to know that the moral foundation is weak and resultantly all such incidents can happen in future as well.

Uma. They knew. Anarkali, Champa and all Hijra people knew who was behind the killing of Kamla. They have no voice. The case was hushed up and was not even reported in the newspapers. Champa was right. The police made no arrests. Subbu's suicide was written off as an accident. The photograph was destroyed. So were the lives of two young people.

\section{CONCLUSION}

The playwright's portrayal of the realities of the contemporary English society certainly lead us to conclude that all claims of amelioration of social injustice prove illusionary. There is something to declare and something else on what we call ground zero. The rich and well-off enjoy special place of security in society. There are solemn declarations of concern for the marginalized people but it's sheer hypocrisy. Dattani mocks this hypocritical approach of the English people. 'Seven Steps around the Fire' also lashes at this dubious policy. There is no doubt that Dattani's plays are an appeal to the readers to amend their attitude towards these unfortunate people. There are characters from the weaker sections who show some grit in facing age-old tyranny of the powerful, but they too submit to the reality of power and wealth in the end. Uma also bends before this social reality. The plays depict this human psyche that is very difficult to change.

\section{SCOPE}

The present paper has made a sincere attempt to cover a wide range of social realities which find place in Dattani's play under scrutiny here. The research takes up the theme of psychological impact of basic human behavior. It explores the human trait of self-conceit as depicted in 'Seven Steps around the Fire' The research covers all important actors in the play. It evaluates their thought processes in the given situation. It has helped the researcher in holding all essential aspects in the play.

\section{LIMITATIONS}

The stated aim of the research paper here is to focus on the 'world of illusion' through the solemn protestations and mean practices of the characters. So the paper confines its examination to the aspects that are relevant to the said task. It is necessary to strictly adhere to the basic principle of regulated treatment of the theme. Those aspects that have no direct bearing on the stated subject have been carefully kept out of purview.

\section{REFERENCES}

1. Agarwal, Beena. Mahesh Dattani's Plays: A New Horizon in Indian Theatre. Book Enclave, 2008. Agrawal, Beena, Dattani's Theatrical Art and the Tradition of Indian Theatre, appeared in The Dramatic World of Mahesh Dattani A Critical Exploration, Amarnath Prasad, Sarup Book Publishers Pvt. Ltd., New Delhi, 2009.

2. Coles Editorial Board, Dictionary of Literary Terms. New Delhi: Rama Brothers Educational Publishers, 2001.

3. Dattani, M. (2000). Preface.Collected Plays (Vol. 1). Penguin UK.

4. Dattani Mahesh, "An Invisible Observer-a profile by Anita Nair", ( 'An Unveiling of a Playwright in Three Acts.') The Gentleman. May 2001.

5. http://www.anitanair.net/profiles/profile-mahesh-dattani-htm, accession date 2-1-11, Time 23. 15 pm

6. Dattani, M. (2000). Seven Steps Around the Fire. Collected Plays. Vol, 1, 1-42. Nicoll, Allardyce, Quoted in Agrawal, Beena, Mahesh Daatani's Plays A New Horizan in Indian Theatre. Jaipur: Book Enclave, 2008. 